proaching when difficulties may be brought under consideration and discussion.

"There are," Sir John Lubbock remarks, "peculiar difficulties in those cases in which, as among the Lepidoptera, the same species is mandibulate as a larva, and suctorial as an imago." The power of mastication during the first period of life being an advantage, on account of a certain kind of food being abundant, and that of suction during the second, when another kind of food prevailed, or

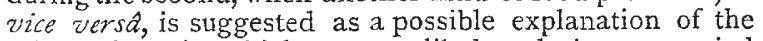
origin of species which are mandibulate during one period of life and not during another. In such cases it is said we have "two forces acting successively on each individual, and tending to modify the organisation of the mouth in different directions." It is suggested that the change from one condition to the other would take place "contemporaneously" with a change of skin. Then it is urged that even when there is no change of form, the softness of the organs precludes the insect from feeding for a time, and when any considerable change was involved, "this period of fasting, it is remarked, would be prolonged, and would lead to the existence of a third condition, that of pupa, intermediate between the other two."

There is much that is assumed in this reasoning; but I shall now venture to call the attention of naturalists to one point only, namely, the analogy between the period of fasting caused by the temporary softness of the organs while the caterpillar changes its skin, and the more prolonged fasting period when the organs undergo that more considerable (!) modification involved in the change from the mandibulate to the suctorial type of mouth. The change from a small mandibular apparatus to a larger one seems to be compared with the change from a mandibular to a suctorial apparatus - the change of skin of the caterpillar with the change of skin when the caterpillar becomes the pupa, and the latter the imago-the temporary softness which prevails when the little mandibles grow into bigger mandibles, with the temporary softness which prevails while the mandibles become converted (!) into the suctorial mouth. But these changes are surely of different orders, and the operations of a different nature. The mandibles do not change. The one type of mouth does not pass through gradations of any kind into the other kind of mouth. But one abruptly ceases, its work having been discharged, while the other is developed anew. As compared with the change of skin of the caterpillar, the change of skin from chrysalis to butterfly is indeed a "considerable change." It would require an amazing intelligence to premise from the study of a caterpillar that from it, after certain chânges of skin and periods of rest, would emanate a butterfiy.

It is very well to suggest that "in reality the necessity for rest is much more intimately connected with the change in the constitution of the mouth"; but what, I would ask, is the evidence of the connection implied? Between the change from the small mandibles to the large, and the change from the latter to the suctorial apparatus, there can be no comparison-no analogy, for the suctorial mouth is developed anew during the pupa state, and its formation is not commenced until all traces of the mandibles are gone. Nay, every tissue of the caterpillar disappears before the development of the new tissues of the imago is commenced. The muscular and nervous systems of the latter are as different from those of the former as are the digestive apparatus, the oral mechanism, and the external covering. These organs do not change from one into the other; but one, having performed its work, dies, and is removed entirely. Not a vestige of it remains. Its place is occupied by formless living matter, like that of which the embryo in its early stages of development is composed; and from this formless matter are developed all the new organs so marvellously unlike those that preceded them; and others unrepresented at all in the larval stage, make their appearance. To explain, according to Mr. Darwin's theory, the "period of change and quiescence" intermediate between the caterpillar and imago states of existence, is likely to remain for some time a very difficult task. If the difficulty cannot be resolved until the period of quiescence during which the imago is formed, is proved to be analogous to the periods of quiescence during the change of skin of the larva, the life history of a butterfly will remain for a long time a puzzle to Mr. Darwin and those who believe in the universal application of his views.

LIONEL S. BEALE

\section{ON THE RECURRENCE OF GLACIAL PHE- NOMENA DURING GREAT CONTINENTAL EPOCHS}

$I^{N}$ the August number of the Geological Society of London I published two papers "On the Physical Relations of the New Red Marl, Rhæetic Beds, and Lower Lias," and "On the Red Rocks of England of older date than the Trias." In the latter I attempted to prove that for the north of Europe and some other parts of the world, a great Continental epoch prevailed between the close of the upper Silurian times and the end of the Trias or commencement of the deposition of the Rhætic beds; in other words, that the Old Red sandstone, Carboniferous strata, Permian beds, and New Red series were chiefly formed under terrestrial conditions, all, with the exception of the Carboniferous series, in great lakes and inland seas, salt or fresh.

The Permian strata, in particular, appear to have been deposited under conditions to which the salt lakes in the great area of inland drainage of Central Asia afford the nearest modern parallel.

While brooding over the whole of this subject for several years past, I have often been led to consider its bearing on those recurrent phenomena of glacial epochs which now begin to be received by many geologists.

The phenomena of moraine-matter, scratched stones, and erratic boulders, whether deposited on land by the agency of glaciers, or in the sea and lakes by help of floating ice, are evidently intimately connected with the contemporary occurrence of large areas of land, much of which may, or probably must, have been mountainous.

The late Mr. Cumming, in his History of the Isle of Man, "hints at the glacial origin of certain Old Red conglomerates in that island, conceiving that the bony external skeletons of some of the fish of the period may have been provided to enable them to battle with floating ice. In lectures and in print I have frequently stated my belief that the brecciated subangular conglomerates and boulder beds of the Old Rec sandstone of Scotland and the north of England are of glacial origin, so distinct, indeed, that when these masses and our recent boulder clay come together, there is often actual difficulty in drawing a line of demarcation between them. I frequently felt this difficulty years ago, when, commencing the Geological Survey of Scotland, I mapped the strata in the country south of Dunbar, and the same difficulty was occasionally felt by others in the valley of the Lune, near Kirkby Lonsdale.

If, as I believe, the Old Red sandstone was deposited in inland Continental waters, the Grampians, as a mountain' tract, bordered these waters, and they must have been much higher then than now; not only because of the probably greater elevation of the whole continent, but also because the Grampians formed land during the whole of the Upper Silurian epoch, and suffered great waste by denudation, then and ever since. The glaciers of these mountains marked an episode in Old Red sandstone times, and yielded much of the material of the boulder beds of the Old Red sandstone.

In these regions and in North America, the Carboniferous 
strata were evidently formed under the influence of "a warm, equable and moist climate," and I know of no glacial phenomena in connection with this epoch.

But respecting Permian times I attempted in 1855 to prove the existence of ice-borne boulder beds during part of that epoch, and by degrees this opinion has been more or less adopted. These boulder beds were derived by glacial transport from the mountains of Wales, which then, also, were necessarily much higher than now. As the Old Red boulder beds were formed during a glacial episode or episodes of parts of that epoch, so the Permian boulders mark another glacial episode occupying part of Permian time, just as our last great glacial epoch formed an episode in those late Tertiary times of which the present time forms a part. At the time of the publication of this paper, I conceived the Permian boulders to have been deposited in the sea by the agency of icebergs, but I now consider them to have been deposited in inland lakes.

This, if true, formed a second glacial epoch, of unknown intensity, during the long continental period that lay between the close of Upper Silurian and the beginning of Liassic times.

During the Triassic period there is no certain sign of glacial phenomena in the British area.

$I$ have elsewhere attempted to show that at the present day there is an intimate connection between past glacial phenomena and the occurrence of lakes, large and small, many of which are true rock-bound basins.

I further believe that this cause would be found to characterise ancient Continental recurrent glacial epochs through all past time, if perfect data were accessible, or had been preserved from destruction by denudation and disturbance of strata. In the Palæozoic cases mentioned above, there is, in my opinion, an evident connection of some kind between inland lakes and glacial action, and in stating this it must be borne in mind that $I$ do not consider the Old Red and Permian strata of Britain to have been deposited solely in two lake basins during two epochs, but in various basins during each of two special eras of geological time. For example, the Magnesian Limestone beds of Yorkshire and Northumberland were formed in a hollow quite distinct from the great conglomerates (locally called "brockram") and sandstones of the Vale of Eden. Prof. Harkness in $1856 \%$ showed that in the South of Scotland Permian beds, partly formed of brecciated conglomerates, lie in rocky hollows entirely surrounded by lips of Silurian and Carboniferous strata, in fact, in rock basins; and he attributed this singular circumstance to a sinking in of the Silurian strata in each case underneath the Permian rocks.

Ever since the publication of my paper, in 1862 , on the Glacial origin of certain lakes in rock basins, I have suspected that these Permian rock basins may also have been scooped out by the agency of glacier ice. I connect this view with my paper on Permian glaciers, published in the Geological fournal in 1855 , but as I have not yet seen the country where these hollows lie, I have not been able either to verify or disprove this supposition. I expect, however, that some day this view will be proved, not for these areas alone, but for others of larger area and very different date, which as yet I have only partially examined, in other European countries.

The unravelling of nearly all stratigraphical phenomena of every geological age resolves itself simply into attempts to realise ancient physical geographies, and we may rest assured that those forces that are now in action have played their part in the world sometimes with greater, sometimes with less intensity, through all known geological time, as far as it can be studied by an examination of the rocks that form the crust of the earth. If glacier ice scooped out many lake rock-basins in the latest great glacial epoch, it did the same during glacial epochs of earlier date.

A. C. RAMSAY

\section{WOOD'S "INSECTS AT HOME"*}

THIS bulky volume of 670 pages appears to us to be altogether a mistake. It is far too voluminous and too uninteresting for a beginner, while for the more advanced student it is almost valueless, being a very incomplete compilation from the works of well-known writers. It consists of brief and imperfect descriptions of a selection of, perhaps, one-twentieth of the insects inhabiting Great Britain, with occasional notices of their habits and economy, and extracts from a few entomological works. These descriptions are generally introduced by such words as "Our next example," "We next come to," "We now come to," "Next in order comes," "Next on our list is," \&c. \&c. ; and for the most part are mere amplifications of short technical characters, conveying a minimum of useful information, with a maximum expenditure of words. Let us take two examples at random. At p. 76 we have two-thirds of a page devoted to a beetle :-

"Our first example of the Staphylinidæ is one of the finest, in my opinion the very finest, of that family. It is called scientifically Creophilus maxillosus, but has, unfortunately, no popular name, probably because it is confounded in the popular mind with the common black species, which will be presently described. Its name is more appropriate and expressive than is generally the case with insect names. The word Creophilus is of Greek origin, and signifies 'flesh-lover' while the specific title, maxillosus, signifies 'large-jawed.' Both names show that those who affixed them to the insect were thoroughly acquainted with its character and form, for the Beetle is a most voracious carrion eater, and has jaws of enormous size in proportion to its body. The colour of this beetle is shining black, but it is mottled with short grey down.

"In some places this Beetle is tolerably plentiful, but in others it is seldom if ever seen. It can generally be captured in the bodies of moles that have been suspended by the professional mole-catchers, and, indeed, these unfor tunate moles are absolute treasure-houses for the coleopterist, as we shall see when we come to the next group of Beetles. A figure of this insect is given on woodcut No. viii. Fig. 3. It is the only British insect of its genus which is distinguished by having short and thickened antennæ, smooth head and thorax, and the latter rounded."

The descriptive portion of this characteristic passage could be easily compressed into two or three lines. In the other twenty we are told that the original describers of the insect were well acquainted with it, that the public are not, and that moles caught by professional mole-catchers are unfortunate!

Turning to page 447 , we have a moth described as follows :-

"The first family of the Geometræ is called Urapterydæ, or Wing-tailed Moths, because in them the hinder wings are drawn out into long projections, popularly called 'tails.' In England we have but one insect belonging to this family, the beautiful, though pale-coloured, swallowtailed moth (Urapteryx sambucata). The generic name is spelt in various ways, some writers wishing exactly to represent the Greek letters of which it is composed, and others following the conventional form which is generally in use. If the precisians are to be followed, the word. ought to be spelt Ourapteryx.

"There is no difficulty in recognising the moth, the colour and shape being so decided. Both pairs of wings are delicate yellow, and the upper pair are crossed by two narrow brown stripes, which run from the upper to the lower margin. These stripes are very clear and well defined, but besides these are a vast number of very tiny

* "Insects at Home: Being a Popular Account of British Insects, their Structures, Habits, and Transformations." By the Rev. J. G. Wood, M.A., F.L.S., \&c. With upwards of 700 Figures by E. A. Smith and J. B. Zwecker, Engraved by G. Pearson. (Longmans, Green, and Co. I872.) 